\title{
Abu Muslim Al-Khurasani: The Legendary Hero of Abbasid Propaganda
}

\author{
Huzaifa Aliyu Jangebe \\ (Master's Student, Department of History and Civilization, International Islamic University, Malaysia)
}

\begin{abstract}
This paper narrates the events of Abu Muslim al-Khurasani's inglorious life. Loved by some and feared and hated by others, Abu Muslim proved to be a man of substance, throughout his life. The paper begins with the introduction, detailing about how he came into play, during disputes with the Umayyad caliphate. It goes on to discussing conflicting views about Abu Muslim's origin, how one believes him to have come from a prestigious lineage, while the other considers him merely a slave boy, with lucky stars. Following Abu Muslim's background is a discussion of his contributions in the Abbasid propaganda, which led to a series of events, which eventually led to the worst massacre in all of Khurasan history, the end of the Umayyad caliphate and the birth of the Abbasid caliphate. The paper goes on to discussing Abu Muslim's tenure as the governor, in the Khurasan, which despite of racial and religious differences, turned out to be a good example of his role, in history. This also led to a difference of opinion with other ruling parties, including his conflict with The Abbasid. Because of this conflict, Abu Muslim made a lot of enemies, which resulted in others rebelling and propagating against him, which eventually took his life.
\end{abstract}

Keywords: Abbasids, Propaganda, Umayyads, Khurasan, Caliphate.

\section{Introduction}

The Abbasid propaganda was the first major revolution in the Muslim world, which resulted in the destruction of the Umayyad dynasty and its replacement by Abbasid caliphate 750 C.E.

Caliph Muawiya's (661 C.E) establishment of the Umayyad caliphate corresponded with the assassination of Caliph Uthman bin Affan, a result of which was Muawiya's demand from Caliph Ali ibn AbiTalib, of the prosecution of the assassinators. This request characterized the undisputed relationship of the two Caliphs. In time, the Umayyad caliphate was re-strengthened under Abdul Malik (685-705 C.E), and later, during Caliph Umar II's ${ }^{1}$ reign, the caliphate transformed into an all Muslim dynasty, but it failed to continue thus, as his successors were unable to cope with its demands, and make significant contributions to the development of the caliphate. ${ }^{2}$

The internal dispute about the hereditary between the Umayyad families has been marked as one of the major factors that contributed to the downfall of the Umayyad regime, in general and Khurasan, in particular. When al-Walid II became Caliph, he imprisoned a number of sons of Caliph Yazid b. Hisham and Walid bin Abdulmalik, merged Khurasan under Iraq and dismissed its governor Nasr b. Sayyar. ${ }^{3}$ Notwithstanding, his cousin Yazid bin al-Walid revolted against him. ${ }^{4}$ This resulted in the death of the latter, and the beginning of Yazid III's tenure. During his time, he appointed Abdullahi bin Umar bin Abdul-Aziz as the Governor of Iraq, and Khurasan was again handed over to Nasr b. Sayyar.

Marwan II was the last Caliph from the Umayyad caliphate. During his reign, the Khawarij rebelled against him several times, but without success. During this time, Yazid b. Umar invaded Iraq and maintained Nasr b. Sayyar as the governor of Khurasan. These circumstances caused the Abbasid propaganda to reach its peak. This progress sped up when Muhammad bin al-Hanafia joined Abbasids and formed a consolidated group. Subsequent upon this, Imam Ibrahim became the leader of the Abbasid propaganda (Daawah). He based the movement on consistent principles and assigned missionaries to Islamic provinces like Syria, Hijaz and Khurasan. Fortunately, for the Khurasan province, Imam Ibrahim came across Abu Muslim who shouldered the responsibility of taking the mission towards victory. ${ }^{5}$ Eventually, Abu Muslim managed to raise the campaign against the Umayyad rule successfully, which toppled the Umayyad regime, not only in Khurasan, but all over the Islamic community. However, despite his vital role, Abu Muslim was finally assassinated by the second Abbasid Caliph Abu Jaafar al-Mansur, in 755 C.E. This paper highlights how Abu Muslim succeeded in

\footnotetext{
${ }^{1}$ M.A Shaban, The Abbasid Revolution. (Cambridge: Cambridge University Press, 1970), 88.

${ }^{2}$ Akbar Shah, Najeebabadi, The History of Islam, Vol II, (London: Darussalam International Publication Ltd, 2000$), 186-87$.

3 Ibid, 219.

${ }^{4}$ Shaban, 134.

${ }^{5}$ Najeebabadi, 257-258.
} 
producing tangible results and establishes his power in Khurasan. It also discusses his great contributions in the emergence of the Abbasid rule.

\section{The Origin of Abu Muslim}

Different views, regarding the origin of Abu Muslim, have been jotted down by historians. Though scholars have tried to discover and trace his root, the discovery is, nevertheless, wrapped in impenetrable paradox. ${ }^{6}$ Two contradictory views emerged, the first, pro-Abu Muslim believe him to be a free man, who emanated from a noble descent, while a second, anti-Abu Muslim views portray him as a slave, with suspicious genealogy, ${ }^{7}$ and "a saddler's slave who motivated slaves in Khurasan to kill their masters". ${ }^{8}$ According to the former group, Abu Muslim was actually named Ibrahim Ibn Uthman bin Yasar bin Shadus bin Judirn. His father fled from his home town for reasons best known to him, and settled in Fatiq, in Isfahan, where he met Isa bin Maaqil bin Umayr al-Ijli. After his death, his slave girl gave birth to a boy (Abu Muslim) and Isa raised him as his own son. ${ }^{9}$ Other different claims also emerged from this particular group of people, regarding Abu Muslim's descent. The second group affirms that Abu Muslim was associated with Bani Ijl, but only as his slave. In addition to this, the latter group has another number of claims against Abu Muslim. They claimed that Ibrahim bin Uthman bin Yasar sold the pregnant slave girl to Isa bin Maaqil. ${ }^{10}$ In al-Maqrizi`s notes, it was reported that Abu Muslim was Yunus bin Asim's slave. More so, Bukayr bin Mahan was the one who bought him from Yunus bin Asim for 400 dirhams and sent him to Imam Ibrahim, the commander of Abbasid propaganda. ${ }^{11}$

According to Najeebabadi, Abu Muslim's real name was Ibrahim bin Uthman bin Bashar, and at the time his father passed away, he was only seven years old. He was then brought up by his master Isa bin Musa Sarraj, until he was jailed by the Umayyads. That incident motivated Abu Muslim to revolt against the Umayyad Caliphate. In order to grab this opportunity, Qahtabah bin Shabib presented him to Imam Ibrahim, who shared the onus of propagating the Abbasid ideas to the inhabitants of Khurasan. Thus, with the permission of Isa, Qahtaba invited Abu Muslim to accompany him, and they left for Hamimah. Abu Muslim was renamed Abdurrahman, by Imam Ibrahim, and he was given the laqab (byname) of "Abu Muslim", which in time replaced his real name, and borrowed him from Qahtaba b. Shabib. Then onwards, until the establishment of the Abbasid Caliphate, ${ }^{12}$ Abu Musa was part of the Abbasid revolution.

Different writers represented different views of Abu Muslim's origin, because all Abbasid propagandists intentionally concealed their racial and geographic origins, to achieve their secret propaganda. More so, Abu Muslim was himself reluctant to answer any question relating to his lineage. Instead of answering the interrogators, he casually told them to "ignore that area", because it was not important. ${ }^{13}$

Thus indeed, Abu Muslim al-Khurasani was merely a character found by Imam Ibrahim, to play a significant role in a campaign against Umayyad caliphate, and to promote the Abbasid revolution in Khurasan. According to the available literature, we can conclude that Abu Muslim was originally from Khurasan, who was used to manipulate the campaign and the revolution from the Khurasan region. ${ }^{14}$ Finally, based on the contradictory information on Abu Muslim's origin, it is clear that to trace his origin precisely is quite impossible.

\section{Contribution of Abu Muslim To Abbasid Propaganda}

The role of Abu Muslim al-Khurasani in Abbasid propaganda was crucial. ${ }^{15}$ In $129 \mathrm{AH}$, on his way to hajj, he received the permission from Imam Ibrahim, to transform the secret campaign into an open revolution. ${ }^{16}$ He immediately returned to Merv and concentrated on territorial gain. However, to achieve the success of the campaign, Qahtaba bin Shabib was appointed by Imam Ibrahim as the military commander of the forces of the Hashimiyya in Khurasan. Thus, Abu Muslim accepted the appointment and allowed Qahtaba to lead the campaign. $^{17}$

\footnotetext{
${ }^{6}$ Ibn Khillikan, Ahmad ibn Muhammad, Wafayat al-A ayan, vol.3, (Beirut: Dar -Sadir, 1900), 145.

${ }^{7}$ Daniel, Elton L, The Political and Social History of Khurasan Under Abbasid Rule 747-820 (Chicago: Bibliotheca Islamica, 1979$)$ ), 101.

${ }^{8}$ Faruq Umar, The Abbasid Caliphate 132/750-170/786 (Baghdad: Baghdad university, 1969), 78.

${ }^{9}$ Ibn Khillikan..., 147.

${ }^{10}$ Sharon, Moshe, Black Banners From the East: The Establishment of the Abbasid State-Incubation of a Revolt, (Jerusalem: The Magnes Press, 1983), 206.

${ }^{11}$ Al-Maqrizi, Ahmad bin Ali, Al-Maqrizi s Book of Contention and Strife Concerning The Relations Between The Banu Umayyad and The Banu Hashim, (Manchester: University of Manchester, 1980), 91.

12 Najeebabadi, 259.

${ }^{13}$ Shaban, 153.

${ }^{14}$ Al-Tabari, Abu Jaafar Muhammad b. Jarir, The History of al-Tabari (Tarikh al-Rusul wa al-Muluk): The Abbasid Revolution A.D 743750/ A.H 126-132, Volume XXVII, trans. John Alden Williams (Albany: state University of New York Press, 1987), 61-62.

${ }^{15}$ Matthew Godon, The Rise of Islam, (U.S.A: Greenwood Press, 2005), 47.

${ }^{16}$ Al-Tabari, The Abbasid..., 62.

${ }^{17}$ Hawting, G. R, The First Dynasty of Islam: The Umayyad Caliphate AD 661-750 (London: Croom Helm, 1986), 115-116.
} 
This period coincided with the battles between Kirmani and Nasr bin Sayyar, in Khurasan. Abu Muslim grasped the opportunity and placed his men between Kirmani and Nasr bin Sayyar tents. After a clash between the two forces, Kirmani was killed, and his son Ali bin Kirmani joined Abu Muslim, to strengthen his forces. Due to this enforcement, Abu Muslim and his alliance managed to expel Nasr from Merv and occupy it. ${ }^{18}$ Although Nasr bin Sayyar sought the assistance from the caliph Marwan, in Damascus, he could not send any assistance, due to the latter's engagement in war with Khawarij in al-Jazirah al-Furatiyyah. ${ }^{19}$ However, at this point, Imam Ibrahim ordered Abu Muslim to kill all Arabic speaking people, along with Umayyad caliphate loyalists, in Khurasan, including Nasr and Kirmani, which Abu Muslim executed. When caliph Marwan II received this news, he immediately instructed the governor of Balqa to arrest Imam Ibrahim at Humayma. Consequently, Imam was arrested and put behind bars. This period was the watershed of the Abbasid conspiracy. $^{20}$

At the beginning of 130 A.H, Abu Muslim took an oath from the people in Khurasan, which the rival groups in the region resented. At that time, there were four rival groups in Khurasan. First was led by Kirmani's son Ali, after the death of his father, while Abu Muslim also gained momentum and became more powerful. Nasr bin Sayyar and Shaiban bin Abdul Aziz were also equally powerful. Abu Muslim prevented any possible act of reconciliation amongst his rivals in the region and grabbed the advantage of this disunity. After Nasr bin Sayyar was defeated in battle, he moved from Marv to Nishapur. ${ }^{21}$ At this juncture, Abu Muslim had already demanded an oath from Shaiban bin Abdul Aziz, who had stationed near Merv, but the latter went against the demand. Immediately, Abu Muslim sent his army to Sarkhas and finally Shaiban was killed.

Gradually, Abu Muslim`s deputies gained victory in Abyuraw and Balkh, respectively. In Balkh, Abu Muslim appointed Yahya bin Naim as the governor of the region. Later on, the latter rebelled against Abu Muslim under the influence of a former governor of Balkh, Ziyad bin Abdurrahman, on behalf of the Umayyad caliphate. Consequently, Abu Muslim sent his army under Abu Dawud, who successfully defeated both Yahya and Ziyad, and captured Balkh once again. In turn, Abu Muslim chose Nasr bin Sabih Muzani ${ }^{22}$ as governor, over Yahya. Gradually, Abu Dawud brought all the Kirmani supporters under the control of Abu Muslim, in Balkh. $^{23}$

After the Qahtaba victory in Tus, while Abu Muslim dispatched Qahtaba bin Shabib to occupy Tus, he intended to attack Nishapur, where Nasr bin Sayyar had taken shelter, but when Nasr bin Sayyar alerted, he fled to Qaumas, which was located on the border between Khurasan and Jurjan. As a result to this, Qahtaba was able to occupy Nishapur, without any resistance, and soon after Nasr left for Jurjan. Qahtaba pursued him again and marched to Jurjan. At this point, Nasr was left with no other choice other than to sought for enforcement from Umayyads and face Qahtaba bin Shabib and his troops. In complying with his request, the governor of Kufa, Nabata bin Hanzala, along with a huge Syrian army, joined Nasr Ibn Sayyar at Jurjan. Eventually, they were joined by an Umayyad army sent from Iraq, by caliph Marwan II. At first stage, Qahtaba bin Shabib`s army was terrified by the news of the enforcement, but they managed to conquer Jurjan and kill 10,000 soldiers and a number of citizens. ${ }^{24}$ The faulty cooperation between the Umayyad commanders in the battle field was the major cause that they lost the war. The chief commander, Nabata bin Hanzala, was killed in the battlefield and Qahtaba bin Shabib won victoriously.

After the battle of Jurjan, Nasr bin Sayyar fled to Khawarurrai. Qahtaba bin Shabib sent his son, Hassan, and another army from the rear to assist him in crushing out Nasr Ibn Sayyar from Khawarurrai. However, Hassan bin Qahtaba was also defeated. Despite his victory, Nasr bin Sayyar moved from Khawarurrai to Rayy, and once again moved to Sada, when he heard about Abu Muslim`s arrival to Nishapur. On his way to Sada, he fell ill and died, after which Qahtaba bin Shabib left Jurjan and marched towards Rayy, and was able to capture it without any struggle, because of Nasr bin Sayyar`s death. ${ }^{25}$

After capturing the Rayy, the path to Iraq was open for Qahtaba bin Shabib. Thus, he went to Isfahan and sent Hassan to capture Nahawand. Subsequently, both places were successfully occupied. More so, Hassan moved on to Halwan and captured it without any difficulty, while he, himself marched to Kufa, with an intention of capturing Iraq. Although it was unsuccessful, it claimed Qahtaba bin Shabib's own life. The Iraqi governor and his army took refuge in Wasit, as a result of which his son, Hassan bin Qahtaba, was chosen, being Qahtaba`s successor, as the leader of the army. Before his death, Qahtaba bin Shabib, had already ordered his

\footnotetext{
${ }^{18}$ Najeebabadi, 262.

${ }^{19}$ Ibn Khillikan, 149.

${ }^{20}$ Najeebabadi,. 262.

${ }^{21}$ Wellhausen, Julius, The Arab Kingdom and Its Fall (Calcutta: Margaret Graham Weir, 2000), 531-34.

${ }^{22}$ Al-Tabari, The Abbasid Revolution, 106; Najeebabadi, 265.

${ }^{23}$ Ibid, Al-Tabari, 104-106.

${ }^{24}$ Najeebabadi, 265-266.

25 Ibid, 267.
} 
son to fight for the establishment of the caliphate of Ali`s supporters, under the leadership of Abu Salama, the head of Daawah in Kufa, and the son acted obediently, on his father's commands. ${ }^{26}$

Imam Ibrahim, however, had already named his brother, Abu al-Abbas Abdallah al-Saffah, his successor, before his death and ordered him to go to Kufa. Accordingly, al-Saffah left Humayma and went to Kufa. When he reached Kufa, Abu Salama had already established a strong influence, under which he intentionally kept the arrival of the Abbasids supporters to Kufa, as he desired to make one of Ali`s descendants as a caliph. ${ }^{27}$ Hence, the people in Kufa were divided into two groups: one supported the reign to continue from the Abbasid family, and other opined that the caliph must come from the descendant of Ali bin Abi Talib.

On the other side, Abu Salama had established himself concretely and opened a discussion with various members of the Alawis family, to offer them the position of caliph. ${ }^{28}$ He personally summoned Imam Jafar al-Sadiq to come to Kufa to be crowned as caliph of the new caliphate, but Imam Jafar al-Sadiq declined. At the same time, Abu Salama promised the caliphate throne to other members of Alwis, to get their support, but there was no sign of any Alwis wanting to be claimed the caliphate. ${ }^{29}$ On the other hand, Abu Muslim had strongly established himself in Khurasan, assuming more power than the governor of Khurasan. He already launched the final stage of the revolution by unfurling black banners, the symbol of the revolt and soon the official color of the Abbasid caliphate. ${ }^{30}$ Politically, Abu Muslim was updated about the situation in Kufa, through his agent, Abu al-Jahm ibn Atiyya. Abu Jahm, was also recognized by Abu Salama in Kufa. However, Abu Salama was merely an administrator, but the revolutionary army control rested in the hands of Abu Muslim's agent Abu Jahm. ${ }^{31}$

Subsequently, in $749 \mathrm{CE}$, Abul Abbas al-Saffah took an oath from his people to establish a new Abbasid Caliphate. That was when Abdallah al-Saffah made his first sermon at the grand mosque and led the Friday prayer. The Caliph al-Saffah went to the governor's headquarters and his brother Abu Jaafar continued to take the oath from the people on his behalf, until late at night. Although Abu Salama took the oath, he was not happy with the new Abbasid caliphate. The emergence of Abul Abbas al-Saffah as Caliph in Kufa and his acceptance in Khurasan marked the establishment of the new Abbasid caliphate. ${ }^{32}$

As soon as Abul Abbas al-Saffah became Caliph, he appointed members of the Abbasid family as governors and commanders of army chiefs in Iraq, Syria, Egypt, and the Arabian Peninsula, ${ }^{33}$ but Abu Muslim remained the governor of Khurasan and a personal adviser of Abul Abbas, whenever he visited Kufa.

To overthrow the last Umayyad caliph, al-Saffah sent Abdallah bin Ali to lead the army in the "Battle of Zab". However, Qahtab bin Shabib's army joined after the fall of Nihawand. In the early 750 CE, Caliph Marwan marched with a huge army from Syrian and Mesopotamians, to meet the Abbasids in battle. Eventually, the Umayyad Caliph was defeated and his army destroyed by the Abbasid forces. Marwan II and his army fled to Egypt. During that time only Damascus was fully under Umayyad control in the Syrian regions. Finally, in the middle of $750 \mathrm{CE}$, the last Umayyad Caliph, Marwan II, was arrested and killed in Egypt, and his head was sent to Caliph al-Saffah in Kufa. The members of the Umayyad family were killed, all over the caliphate. In Syria, even the tombs of the Umayyad were desecrated, with the exception of the tomb of caliph Umar II. ${ }^{34}$ In Khurasan, the provinces witnessed the general massacre in its most horrible form, all the Bani Umayyad and their sympathizers tried to escape from being refugees. ${ }^{35}$ The Umayyad caliphate was demolished, completely; hence, the new Abbasid caliphate emerged.

\section{Abu Muslim: The Governor of Khurasan}

Surprisingly, Abu Muslim successfully managed to rule Khurasan, despite its racial differences coupled with a variety of faiths and beliefs. The Khawarij prepared for a leader who was without secular or religious power. On the other hand, the Shiah believed in the sanctity of Imam with absolute powers to fill the position of Amir al-Mu'Min. ${ }^{36}$ However, Abu Muslim lead them accordingly due to his talent, and gained their love and support, during the revolutionary period. Historians present different views about how Abu Muslim attracted this variety of groups in Khurasan. Some of them claim that Abu Muslim shared each group's beliefs. ${ }^{37}$ This issue led some sources to assert that Abu Muslim had compromised Islam, in order to accommodate different local beliefs.

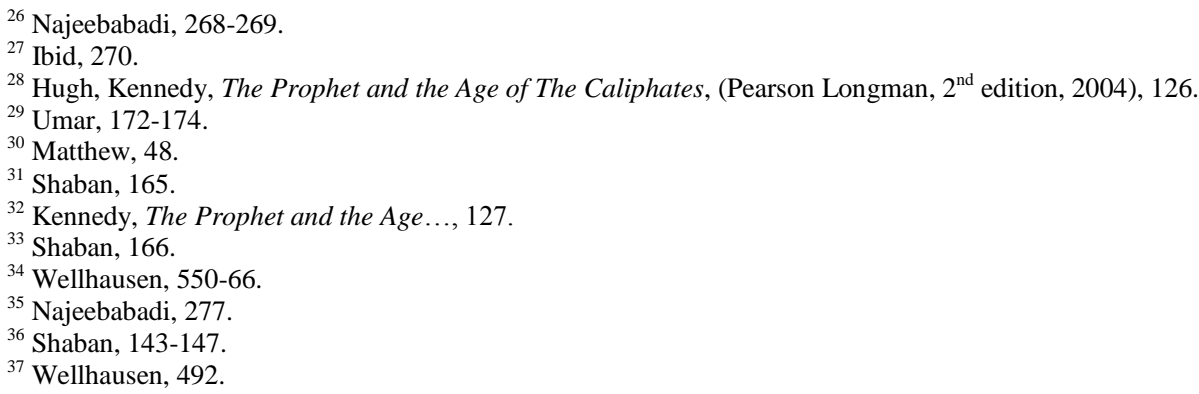


Many Shi`ah perceived Abu Muslim as Shiite and supported him whole heartedly, during the Abbasid revolution. Because of this, Abu Muslim was able to have full control over the Khurasanis population. Ever since Abu Muslim was chosen to lead the revolution, he appointed many Mawalis, as provisional leaders. ${ }^{38}$ As the governor of Khurasan, Abu Muslim managed to defeat any rebellious act and protect the interest of the people, to over throw Umayyad rule in the region.

\section{Conflicts Between The Abbasid Caliphs And Abu Muslim}

The conflict between Abbasids and Abu Muslim started from the earliest stage of its emergence; when the latter saw Abu Salama as the enemy to their new born Caliphate; while the other did not consider it a threat. More so, Abu Muslim's recognition, being the governor of Khurasan, was required before the inauguration, to avert his possible revolt. This was apparent because Abu Muslim was the first threat, at the center of the Abbasid caliphate. According to another conflicting view, Abdallah al-Saffah was a devoted friend to Abu Salama, hence, he fought against the decision to execute Abu Salama. However, Abu Muslim saw it necessary to have Abu Salama killed, because of his hesitation and disloyalty to the caliph. ${ }^{39}$ Contrary to this, other available sources mentioned that Abdallah al-Saffah suspected Abu Salama of possible rebellion against him, in his new position as the governor, right from the beginning of the new caliphate. His disloyalty and struggle to persuade Alawis to accept the caliphate were sufficient evidence. Therefore, he sought the advice of Abu Muslim on how to tackle the issue of Abu Salama. ${ }^{40}$ Accordingly, Abu Muslim sent Murad bin Anas to kill Abu Salama. It has been said that Caliph Abdallah was the one who asked Abu Muslim to send someone, in order to kill Abu Salama, to avoid opposition from Abu Salama`s supporters. ${ }^{41}$ Before Murad's arrival at Kufa, Caliph al-Saffah issued a proclamation to honor Abu Salama and invited him to the palace, where Murad was ready to assassinate him. Later on, a rumor spread, which pinned the minister's assassination on khawarij. ${ }^{42}$

From the events narrated above, it is clear that Abdallah al-Saffah was the one responsible for Abu Salama's murder. However, most of the sources indicate that Abu Muslim was responsible for the murder, because he not only allowed, but also sent the assassin to Kufa. ${ }^{43}$ To clarify this claim, some sources mentioned that the relationship between the Abbasids and Abu Muslim was not merely one of a superior and subordinate; rather Abu Muslim was an important person in the caliphate. He even equated himself to Abu Jaafar, when he visited him in Khurasan, which was the starting point of the conflict of the duo. ${ }^{44}$

Upon his return, Abu Jaafar insisted that the caliph have Abu Muslim killed, in order to establish absolute authority over the caliphate. However, Abu Muslim held an influential position, from the earliest days of the Abbasid caliphate, which transcended over the Caliph himself. This was why his advice was sought before Abu Salama`s murder, so as to avoid the risk of his anger over the execution.

Moreover, after the murder of Abu Salama, Abu Muslim killed Sulaiman bin Kathir as well. Since there was tension between them, when Abu Muslim was sent by Imam Ibrahim to lead the movement in Khurasan, Sulaiman bin Kathir rejected his appointment, on the grounds of him being too young to hold the position. ${ }^{45}$ Whereas Sulaiman, in fact, feared losing his leadership of the movement in the region, since he was the one initially sent for the purpose, and had gained momentum promoting it. It is reported that when Abu Muslim arrived at Khurasan, Sulaiman took up an inkpot and threw it on his face, whereupon the latter got wounded on the forehead. ${ }^{46}$ After this incident, Abu Muslim secretly developed hatred for Sulaiman bin Kathir. On the contrary, Abu Muslim assured Sulaiman that he would always remain loyal to him and would consult him in all matters. ${ }^{47}$ Nevertheless, after establishing his power in Khurasan, Sulaiman was among the first to be executed by Abu Muslim. ${ }^{48}$

Hence, Abu Muslim carried out Imam Ibrahim`s orders and ordered the killings of suspicious people, including his friends and respected personnel in the caliphate. Furthermore, many conflicts and clashes tail between the central government of Abbasids and Abu Muslim. One of them was when caliph al-Saffah appointed his uncle, Isa bin Ali, as the governor of Fars, and upon his arrival, he was refused by al-Khuzai, who had been sent by Abu Muslim to kill all the supporters of Abu Salama. ${ }^{49}$ Gradually, Isa bin Ali was forced to return to Baghdad. This was considered as a clear message for the Abbasids, that Abu Muslim would not

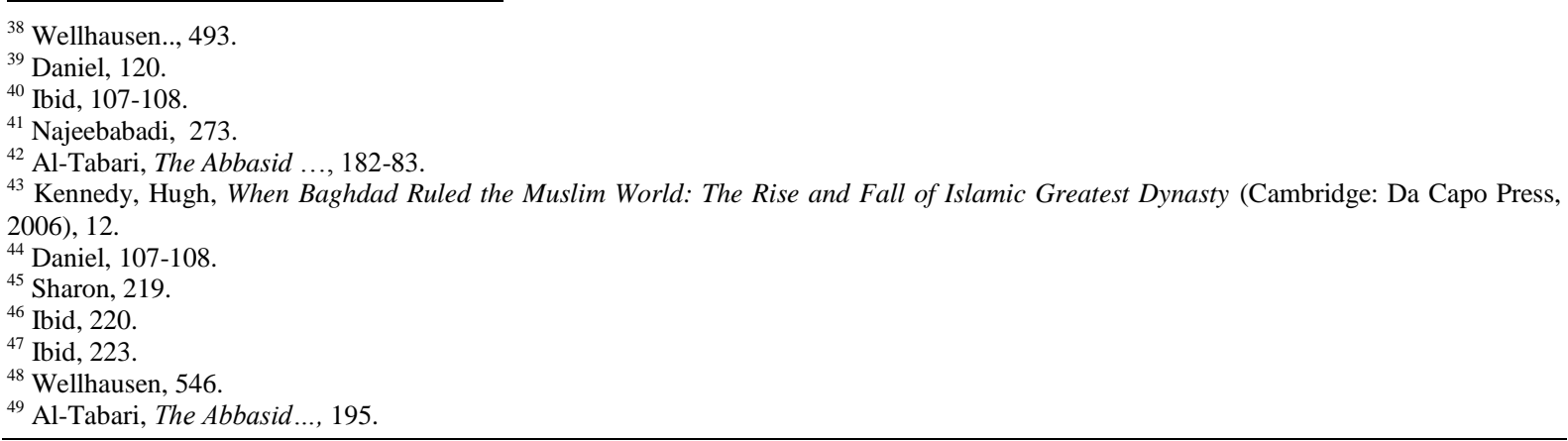


surrender his authority, even to the caliph. After this incident, al-Saffah became suspicious of Abu Muslim, and sought the advice of Abu Jahm. The latter suggested inviting Abu Muslim to the court, and the caliph acted upon that. However, when Abu Muslim accepted the invitation, the caliph's doubts were reduced and he asked Abu Muslim to stay in Khurasan, due to the urgency of the need of his service there. ${ }^{50}$ Perhaps the caliph wanted to observe Abu Muslim's loyalty towards him.

\subsection{The Revolt of Iyad bin Salih}

\section{Revolts Against Abu Muslim}

Ziyad bin Salih, the governor of Bukhara, arose against Abu Muslim, by claiming that he had received a letter from the caliph confirming him as the governor of Khursan. He also urged the people to revolt against Abu Muslim. To avert this rebellion, Abu Muslim investigated the issue and found out that Siba` bin nu`man alAzdi, was played as an agent between the caliph and Ziyad bin Salih. As a result, Abu Muslim ordered his execution. ${ }^{51}$ Then, Abu Muslim marched to Bukhara to suppress the revolt of Ziyad. There he was backed by several supporters, who refused to acknowledge Ziyad's claim. Eventually, Ziyad was killed and his head was sent to the caliph of Baghdad. ${ }^{52}$

\subsection{The Revolt of Isa bin Mahan}

At the same time, Isa bin Mahan revolted against Abu Muslim, by claiming that the Caliph had appointed him as the governor of Khurasan. ${ }^{53}$ Here, Abu Muslim asked Abu Dawud to deal with the issue of Isa bin Mahan. Accordingly, Abu Dawud killed Isa bin Mahan, successfully. The Caliph wrote to Abu Muslim, asking him about the death of Isa and ordering him to kill Abu Dawud, but Abu Muslim defended Abu Dawud, and denied to take any action. However, these plans failed because most of the Khurasanis officers were loyal to Abu Muslim. ${ }^{54}$ These incidents, consequently, led to the conflict between Abu Muslim and the central government in Baghdad.

\section{Abu Muslim Pilgrimage}

In $136 \mathrm{AH}$, Abu Muslim sought permission from the Caliph to perform the pilgrimage to Makkah. Caliph al-Saffah allowed him to go for hajj, but on condition. The Caliph restricted Abu Muslim to take along more than 500 men, ${ }^{55}$ but Abu Muslim defied him and brought over 8,000 men, stationed all the way from Nishapur to Rayy. He went to Baghdad, with the intention to lead the pilgrimage to Makkah, but the leadership of the pilgrimage was entrusted to Abu Jaafar al-Mansur, who was, at that time, the governor of Jazira. It has been said that when Abu Muslim heard about it, he said, "did Abu Jaafar not get another year to his pilgrimage rather than this year?" ${ }^{, 56}$ Many sources state that Abu Muslim wanted to lead the caravan for pilgrimage, in order to increase his popularity and show Abbasids that he was militarily strong enough, and in term frighten them from taking any action against him.

At the end of the pilgrimage season, Abdullah al-Saffah passed away in Anbar, at the age of thirtythree. Because of Abu Muslim`s early departure for hajj, he came across the messenger from the capital, on his way, who carried the news of al-Saffah`s death and Abu Jaafar's succession to the caliphate. ${ }^{57}$ Abu Muslim kept the messenger with him for two days and then let him go to Mansur, ${ }^{58}$ which angered Abu Jaafar. In addition to this, Abu Muslim neither congratulated him, nor did he remain encamped to take the oath, and continued his journey.

\section{Abu Muslim And Abu Jaafar Caliphate}

After the death of Caliph Abdallah al-Saffah, Abu Muslim was not on good terms with Abu Jaafar alMansur, and did not favor him becoming the new caliph. Abu Muslim encouraged Abu Jaafar's nephew, Isa bin Musa, to claim the caliphate. The wrangle between the two had already started, during the pretext of the establishment of the caliphate, when Abu Jaafar went to Khurasan, to take an oath on behalf of his brother. However, at the initial stage of his reign, Abu Jaafar had ordered the execution of Abu Muslim, but he evaded immediate elimination, because his services were crucial, to help them suppress the revolt of Abdullah bin Ali,

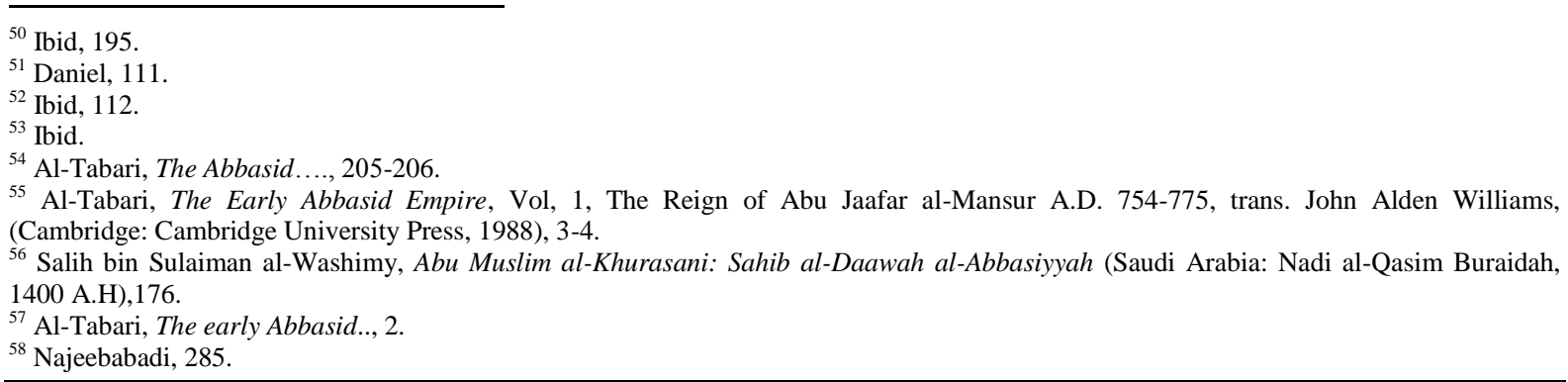


in Syria. ${ }^{59}$ Interestingly enough, Abu Muslim accepted the offer to suppress the revolt, perhaps because Abu Muslim wanted to prove his loyalty to the new caliph.

\subsection{Abdullah bin Ali Revolt}

After the Caliph al-Saffah, Isa bin Musa passed away, the then governor of Kufa, informed Abdullah bin Ali about the caliph's death. Immediately after, Abdullahi bin Ali declared himself caliph, based on alSaffah`s word; his will had declared him the man who led the army to Harran, with the intention of becoming the next Caliph. ${ }^{60}$ Abdallah bin Ali besieged Muqatil bin Harran, and killed several Khurasani men, on suspicion of treason. When Abu Jaafar al-Mansur was informed about Abdullah`s revolt, he alerted Abu Muslim about the threat. This action might have been caliph Mansur`s plan to kill two birds with one arrow, ${ }^{61}$ because the dying of either would be in favor of Abu Jaafar, since the caliph was looking for the right time to murder Abu Muslim. Accordingly, Abu Muslim responded positively and dispatched his army, in order to suppress Abdallah bin Ali`s revolt. Later on, Humaid bin Qahtaba and Hassan bin Qahtaba`s armies joined Abu Muslim forces and assembled at Mosul. ${ }^{62}$ Eventually, after several months of clash, Abu Muslim won victoriously, and Abdullah ibn Ali was defeated. ${ }^{63}$

Having lost the war, Abdullah bin Ali fled to Basra and took refuge with his brother Sulaiman bin Ali. Meanwhile, Caliph Abu Jaafar deposed Sulaiman bin Ali from governorship of Basra and recalled him, asking to bring along Abdullah bin Ali. Even though Abdullah was pardoned by Abu Jaafar, he was imprisoned and died in captivity. ${ }^{64}$

\subsection{Dispute between Abu Muslim and Abu Jaafar}

The relationship between the two worsened after the defeat of Abdullah bin Ali. The conflict arose when Abu Muslim captured the treasury of Abdullah bin Ali, after defeating his army. Upon informed about the Abu Muslims victory, Abu Jaafar sent his man Abu Khasif to make a record of the spoils of war. ${ }^{65}$ Abu Muslim was unhappy with Abu Jaafar's actions, as he had expected to be trusted, in the division of the spoils. Abu Muslim even attempted to kill the messenger, till somebody made him realize that he was not at fault, he was in fact just a messenger. Abu Muslim released him and said, "Should I be entrusted to the blood and not to be trusted on the money." "66 Here, Abu Muslim was very surprised why the caliph entrusted him to crush the rebellion, but did not have confidence in him, when it came to the division of the spoils of the war.

On the other hand, when Abu Jaafar came to know of Abu Muslim's displeasure, he immediately appointed Abu Muslim as the governor of both Syria and Egypt. ${ }^{67}$ This might be in order to avoid Abu Muslim's disobedience, when going back to Khurasan, as its governor. When Abu Muslim learnt about this, he refused the appointment, thinking that he was being separated from Khurasan, to make him helpless and powerless. Thus, Abu Muslim decided to leave for Khurasan, against the wishes of the Caliph.

Abu Jaafar used all his means to persuade Abu Muslim, to accept the transfer, but all in vain. Finally, Abu Muslim declined the post, and maintained his governorship in Khurasan, ${ }^{68}$ and this left little doubt in Abu Jaafar's mind that Abu Muslim would revolt any moment.

\section{The Assassination of Abu Muslim}

After several attempts, Abu Jaafar sent for Abu Muslim to visit him, but he refused saying, "I shall obey you from a distance. I have subdued all your enemies. Now that all your dangers are over, you do not need me. If you leave me alone, I shall keep obeying you and shall remain committed to my oath. But if you pursue me, I shall announce the cancellation of the oath and oppose you." After receiving the letter, Abu Jaafar replied to him very softly, in order to clear the doubts he had in his heart. ${ }^{69}$

At this juncture, al-Mansur changed his plan, wherein he used Abu Muslim`s closest people to persuade him. He asked Abu Dawud to convince Abu Muslim to visit, in exchange for the governorship of Khurasan. ${ }^{70}$ Finally, Abu Muslim accepted Abu Dawud's advice and agreed to visit the Caliph. However, Abu Muslim took precautions by sending Abu Ishaq bin Uthman, whom he trusted most, to investigate the situation in the caliph`s

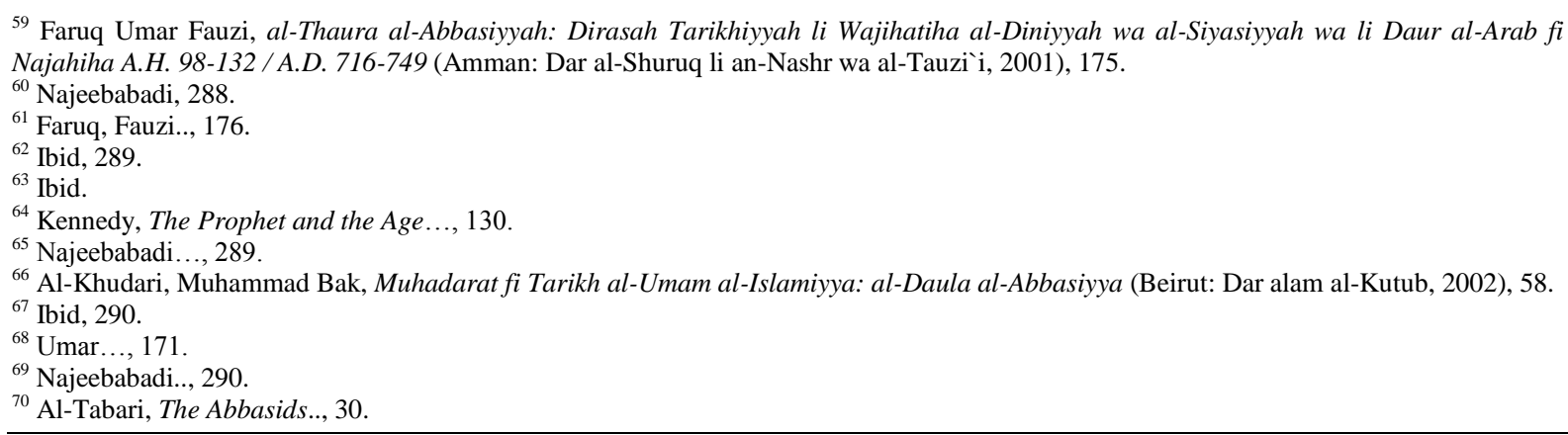


court, but, Abu Jaafar used Uthman to convince Abu Muslim, to come to him, in exchange for the governorship of Khurasan. ${ }^{71}$ Then, he returned to Abu Muslim and persuaded him to visit Caliph Mansur. According to Jurji Zaidan, Salih ${ }^{72}$ was the one who advised Abu Jaafar to move to Madain, in order to receive Abu Muslim there, by saying Madain was the city where Muslims defeated the Persians victoriously, and by God's grace, will be the city where Abu Muslim would be defeated. ${ }^{73}$

However, when Abu Muslim arrived at a place outside Madain called Rumiyya, Abu Jaafar ordered several of Hashimiyyah noblemen to welcome Abu Muslim. At that time, Abu Muslim was restricted from seeing the caliph, for three days. At this point, Abu Salih inquired al-Mansur about what was going on, and he replied, "We left him to become calm, and then we can see". When Salih heard that, he was frightened and said, "To see what? Kill, then kill, if you do not kill him he will murder you." After listening to this Al-Mansur laughed and added, "Don't worry, two men never clash in a jungle, unless one of them killed the other one." After listening to this, Salih calmed down. ${ }^{74}$

On the third day, the caliph called for Abu Muslim. Before Abu Muslim's arrival, Abu Jaafar ordered the head of his bodyguards, Uthman bin Naheek, Shabeeb bin Rawah, Harb bin Qais and two others, to hide behind a veil and instructed them to come out and kill Abu Muslim when he clapped. ${ }^{75}$ When Abu Muslim entered, Abu Jaafar asked him about the swords he had taken from Abdullah bin Ali; Abu Muslim immediately handed over the sword to Abu Jaafar al-Mansur, which he put under his bed. Subsequently, Abu Jaafar charged him with several misdemeanors and Abu Muslim responded positively. Suddenly, Abu Jaafar asked him, "Was it not you that wrote to me, while started with yourself before me, asking to marry my aunt Aminat bint Ali, claiming to be son of Salit ibn Abdullah ibn al-Abbas? You have climbed the most difficult ascent." 76 These were the first words which budged Abu Muslim's anger, but he suppressed his fury and remained silent. Although Abu Muslim initially offered excuses humbly, Abu Jaafar's anger arose. After a long admonition, Abu Muslim replied angrily, "Do what you may, I fear none except Allah." At this juncture, the anger of Caliph Abu Jaafar rose, he immediately clapped his hands, and then the conspirators pounced on Abu Muslim and stabbed him to death. ${ }^{77}$ Abu Muslim was murdered in 137 A.H/ 755 C.E. When the news of his death reached Hanzala, he arrived and saw his dead body. He said, "Amir al-Mu'min you are the Caliph with effect from today." His dead body was thrown into the Tigris River. ${ }^{78}$ The assassination triggered a number of uprisings in some provinces of Khurasan.

\section{Uprisings After Abu Muslim`s Death}

Despite the fact that Caliph Abu Jaafar had gained complete control of the Abbasid caliphate, he faced many uprisings from the Khurasan region after the assassination of Abu Muslim.

\subsection{The Uprising of Sinbad}

Sinbad's originally named Fairoz converted to Islam and joined Abu Muslim`s Army. After Abu Muslim`s death, he demanded the compensation for Abu Muslim`s assassination and he was supported by some of the dwellers of the mountain areas. Eventually, he captured Nishapur and Rayy. He looted money from the people and forced them into slavery. Then he turned apostate and announced that he was going to destroy the Kaabah. Most of his supporters were Iranians, who knew little about Islam and the revolt against the Abbasid caliphate. When Caliph Mansur informed about the revolt, he asked Jamhur bin Murad to crush Sinbad. The two fought at a place between Hamadari and Rayy. Eventually, Jamhur defeated Sinbad, and the latter fled and took refuge in Tabristan, where he was killed by a servant of the governor of Tabaristan. ${ }^{79}$

Abu Jaafar requested the governor of Tabaristan to send Sinbad`s wealth, but he refused and fled to Dailama. Similarly, Jamhur captured all of Sinbad's Abu Muslim`s treasury, and fled to Rayy, where he denounced his oath to Mansur and rebelled against the caliph. As a result, Mansur asked Muhammad bin Ashath to fight Jamhur. Therefore, Jamhur fled first to Isfahan, and then to Azerbaijan. Finally, Jamhur was killed by his own friends, and his head was handed over to Caliph Mansur. ${ }^{80}$

\footnotetext{
${ }^{71}$ Daniel, 115.

${ }^{72}$ Salih was among the men behind Abu Muslim murder, it had been said that he contributed greatly in the process to assassinate Abu Muslim. Later on when Abu Muslim faience (Janral daughter of Merv King) exposed him, he was killed by Abu Jaafar al-Mansur. For full detail, See: Jurji Zaidan, Abi Muslim al-Khurasai, (Beirut:al-Maktaba al-Adabiyya, 1970).

${ }^{73}$ Ibid, 167.

${ }^{74}$ Ibid.., 170

75 Ibid, 171.

${ }^{76}$ Ibid, 171 .

${ }^{77}$ Najeebabadi, 291; Jurji, 171-172.

${ }^{78}$ Shaban, 168

${ }^{79}$ Najeebabadi, 292.

${ }^{80}$ Najeebabadi, 292; al-Tabari, The Early Abbasid...., 37- 40
} 


\subsection{The Uprising of the Rawandiya}

The sect members were originally recruited by Abu Muslim, in his army. According to Najeebabadi, the sect can be regarded as one of the Shi ah sects, which comprised ignorant people from Rawanid. It is asserted that they professed the transmigration of the souls. They, thus, claimed that the soul of Adam was in Uthman bin Nahik, and that Caliph Mansur was their lord. They penetrated the capital and propagated their faith publically. When Caliph Mansur tried to deal with them, they besieged his palace. Nevertheless, at that moment the caliph's army was not available to defend him. As a result, he underwent a very critical moment. Maan bin Zaidan, ${ }^{81}$ Grasped the opportunity and assisted Caliph Mansur, with the help of other civilians, but his attack proved most effective and he successfully managed to crush the rioters. After the battle, Caliph Mansur granted him pardon, excused his past crimes and promoted him to a higher rank. ${ }^{82}$

\section{Conclusion}

Abu Muslim led the campaign and dealt with it against Umayyad in Khurasan effectively. However, the man was sent by Imam Ibrahim as the leader of Abbasid daawah in the region. Consequently, after fighting a number of battles, Abu Muslim became the governor of Khurasan. As a result, the Umayyad position in Khurasan became untenable. And that marked the victory of Abu Muslim, while on the other hand indicated the starting point of the termination of the Umayyad rule in the region.

Eventually, at the beginning of the Abbasid caliphate on several occasions, Abu Muslim proved to be a very important personality in the consolidation of the Abbasid caliphate. In addition, he even served as an advisor to Caliph Abdallah al-Saffah. Furthermore, Abu Muslim killed not only Bani Umayyad, but also those who had supported or served them. The province of Khurasan witnessed the general massacre in its most horrible form. Nevertheless, despite his great contribution to the campaign against Umayyad, in Khurasan, towards the establishment of the Abbasid caliphate, he was executed by the second Caliph Abu Jaafar alMansur, in 755 CE. More so, Abu Muslim exercised his own autonomy even over the Caliph's decision, in executing many important personnel, such as Abu Salama and Sulaiman bin Kathir.

However, Abu Jaafar had feared his ability. The tension between the two reached its zenith after the defeat of Abdullah bin Ali. As such, Abu Jaafar decided to get rid of him, at any cost. His execution became the cause of anger among the people of Khurasan, especially from the Shiite sects. Finally, with the death of Abu Muslim, Caliph Mansur exercised absolute authority all over the caliphate, despite few revolts. Nonetheless, Abu Muslim al-Khurasani's vital contribution in the creation of the Abbasid caliphate is undeniable.

\section{References}

[1] M.A Shaaban, The Abbasid Revolution (Cambridge: Cambridge University Press, 1970)

[2] Akbar, Shah, Najeebabadi, The History of Islam. Vol II. London (Darussalam International Publication Limited, 2000).

[3] Ibn Khillikan, Wafayat al-A yan, Vol III (Beirut: Dar al-Sadir, 1900).

[4] Daniel Elton, The Political and Social History of Khurasan Under Abbasid Rule 747-820 (Chicago: Bibliotheca Islamica, 1979).

[5] Faraq Umar, The Abbasid Caliphate 132/750-170/786 (Baghdad: Baghdad University, 1969).

[6] Sheron Moshe, Black Banners From the East: The Establishment of the Abbasid State- Incubation of a Revolt (Jerusalem: The Magness Press, 1983).

[7] Al-Maqrizi, A. A, Al-Maqrizi Book of Contention and Strife Concerning the Relations Between the Banu Umayyad and the Banu Hashim (Manchester: University of Manchester, 1980).

[8] Al-Tabari, Abu Jaafar Muhammad b. Jarir, The History of al-Tabari (Tarikh al-Rusul wa al-Muluk): Volume XXVII, The Abbasid Revolution A.D 743-750/ A.H 126-132, trans. John Alden Williams (Albany: State University of New York Press, 1983).

[9] Matthew Godon, The Rise of Islam (U.S.A: Greenwood Press, 2005).

[10] G.R. Hawting, The First Dynasty of Islam: The Umayyad Caliphate A.D 661-750 (London: Croom Helm, 1986).

[11] Wellhausen, J, The Arab Kingdom and its Fall (Calcutta: Margaret Gruham weair, 2000).

[12] Kennedy, H, The Prophet and The Age of Caliphates: The Islamic Near East From the Six to The Eleventh Century (2 ${ }^{\text {nd }}$ edn) (England: Pearson/Longman Press, 2004).

[13] Kennedy, H, When Baghdad Ruled The Muslim World: The Rise and Fall of Islam 's Greatest Dynasty (Cambridge: Da Capo Press, 2006).

[14] Al-Tabari, Abu Jaafar Muhammad b. Jarir, The early Abbasi Empire, Volume I, The Reign of Abu Jaafar al-Mansur A.D. 754-775, trans. John Alden Williams (Cambridge: Cambridge University Press, 1988).

[15] Salih bin Sulaiman al-Washimy, Abu Muslim al-Khurasani: Sahib al-Daawah al-Khurasaniyya (Al-Qasim: Nadi al-Qasim Buraida, 1400A.H).

[16] Faruq Umar Fauz, Al-Thaura al-Abbasiyya: Dirasa Tarikhiyya li Wajihatiha al-Siyasiyyah wa li Daur al-Arab fi Najahiha A.H. 98-132/ A.D. 716-74 (Amman: Dar al-Shuruq li an-Nashr wa al-Tauzi i, 2001).

[17] M. B, Al-Khudairi, Al-Daula al-Abbasiyya (Beirut: Dar `alam al-Kutub, 2002).

[18] Jurji Zaidan, Abu Muslim al-Khurasani (Beirut: al-Maktaba al-Adabiyya, 1970).

\footnotetext{
${ }^{81}$ When Yazid ibn Hubayra fought Abbasid forces, Ma`an was one of the Umayyad leaders, so the Caliph had been searching for him but went into hiding.

${ }^{82}$ Najeebabadi, 293-294.
} 